\title{
DEPOIMENTO
}

\section{Luiz Guilherme de Castro}

\section{Orientando alunos no concurso "Soluções para Cidades 2011"}

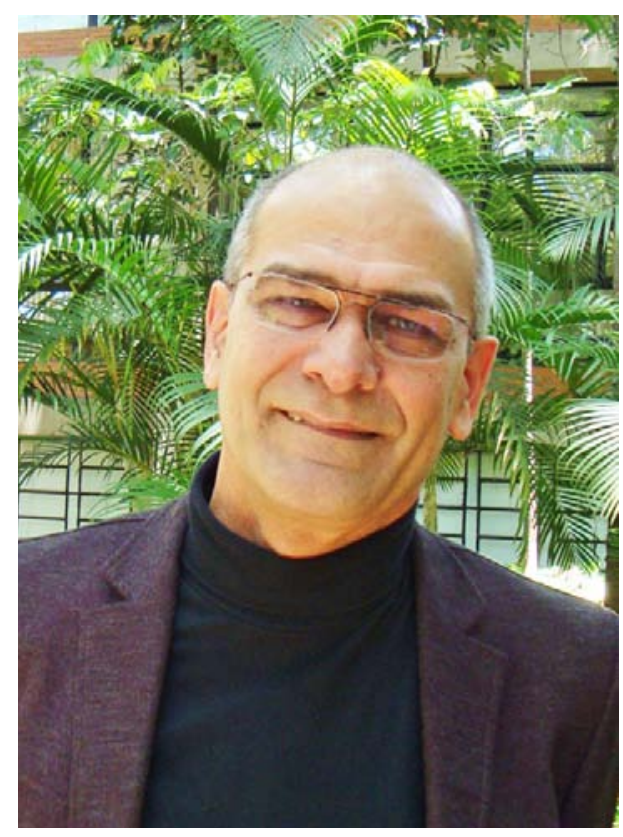

Luiz Guilherme de Castro é arquiteto, graduado pela FAUUSP (1986), mestre em Arquitetura e Urbanismo pela Universidade Presbiteriana Mackenzie (1998) e doutor o em Estruturas Ambientais Urbanas pela FAUUSP (2006).

É professor pesquisador na Faculdade de Arquitetura e Urbanismo da Universidade Presbiteriana Mackenzie, coordenando a sequencia de disciplinas de Planejamento Urbano e desenvolvendo pesquisa sobre temas do urbanismo contemporâneo.

Faço aqui algumas considerações sobre minha participação como orientador no trabalho desenvolvido por Thaila Veronezi e Gustavo Morasco, que obteve a primeira colocação no Concurso Soluções para Cidades de 2011, promovido pela Associação Brasileira de Cimento Portland (ABCP) e organizado pelo Instituto de Arquitetos do Brasil - Departamento São Paulo (IAB/SP).

De início, o tema do concurso, Cidades Cicláveis - Rede cicloviária na cidade de São Sebastião do Paraíso - MG, poderia provocar um certo estranhamento. Não tanto pela participação do IAB-SP como entidade organizadora, posto que as questões urbanísticas, arquitetônicas e as relativas à sustentabilidade fazem parte do campo de conhecimentos e práticas da arquitetura e do urbanismo. A ABCP, entretanto, colocase como "braço técnico da indústria" de cimento e estabelece como sua missão a consolidação e expansão do mercado de produtos e sistemas a base de cimento; a 
representação técnica e institucional da indústria do cimento; a prestação de serviços tecnológicos de excelência e a organização da informação técnica, sua difusão, transferência e capacitação tecnológica ${ }^{1}$. Obviamente, uma das condições colocadas no edital do concurso era a utilização de elementos e sistemas construtivos à base de cimento portland, mas as relações entre a mobilidade urbana e as tecnologias e processos produtivos que empregam cimento não são tão evidentes ou imediatas. $O$ estranhamento se dissipa quando acessamos o portal Soluções para Cidades (http:// www.solucoesparacidades.com.br), mantido pela ABCP, que tem como objetivo a parceria com administrações municipais em três temas principais: habitação, mobilidade urbana e saneamento básico. No portal também vemos que a ABCP mantém convênio com o município de São Sebastião do Paraíso, oferecendo ao município "apoio técnico na elaboração e implementação dos planos de habitação de interesse social, saneamento básico e mobilidade urbana". As informações que podemos obter sobre a gestão urbana em São Sebastião do Paraíso, tanto no portal Soluções para Cidades quanto no próprio portal da prefeitura, trazem outras indicações sobre os objetivos da atual administração municipal visando a melhoria das condições urbanas, ambientais e de vida da população. Essas indicações nos permitem um início de compreensão do contexto, das relações e das articulações que parecem estar na origem do tema do concurso. E que podem nos remeter a considerações mais amplas sobre gestão integrada de políticas públicas urbanas, governança municipal, parcerias públicoprivado e abordagens contemporâneas e inovadoras da gestão e planejamento do território em uma perspectiva de sustentabilidade ambiental, econômica e social. Em minha opinião, o concurso, incluindo seus idealizadores, promotores e organizadores mencionados acima, e também as equipes que apresentaram projetos, mostra um caminho possível para a contribuição projetual e acadêmica a esse amplo debate, colocando em primeiro plano o papel do projeto no campo da arquitetura, do urbanismo e da paisagem.

Ter participado desse processo com Gustavo e Thaila foi muito gratificante, independentemente da premiação. E, óbvio, mais ainda com a premiação do trabalho por eles desenvolvido. $\mathrm{Na}$ entrevista aqui publicada, meus dois jovens companheiros explicaram as circunstâncias de minha participação como orientador do projeto, atribuindome com muita gentileza um papel maior do que penso ter tido. De minha parte, o

1 Conforme nos é informado no portal da ABCP: http://www.abcp.org.br/conteudo/quem_somos/apre sentacao/associacao-brasileira-de-cimento-portland. 
convite feito por eles muito me alegrou, e chegou em um momento bastante singular. Envolvido na coordenação de uma pesquisa sobre o tema dos espaços públicos em seus aspectos conceituais e projetuais ${ }^{2}$, imediatamente vislumbrei a oportunidade de com eles experimentar algumas possibilidades derivadas do trabalho de pesquisa, principalmente as idéias de compartilhamento das vias públicas e da abordagem do espaço urbano e dos lugares públicos em geral como parte de um conjunto de sistemas articulados, não segregados, entre os quais um dos mais importantes é o sistema da mobilidade. A convivência de diferentes velocidades e modos de transporte possibilita múltiplas alternativas de deslocamento, aumentando a acessibilidade geral das pessoas aos muitos benefícios que as cidades proporcionam como local privilegiado do encontro entre as diferenças - diferentes pessoas, diferentes valores, diferentes modos de vida - que podem contribuir para uma sociedade humana menos individualizante e particularista. Nesse caso, a promoção de uma urbanidade menos agressiva, mais amigável e talvez mais cooperativa, em que o uso da bicicleta, da caminhada e dos transportes públicos venham a desempenhar um papel central, relegando a um plano secundário e complementar o uso dos automóveis e todos os prejuízos econômicos, ambientais e sociais que seu uso intensivo e indiscriminado acarreta.

Acompanhar e participar do desenvolvimento do projeto, emitir opiniões, fazer sugestões em relação aos materiais, às questões e aos desenhos que Gustavo e Thaila colocavam, em um processo aberto e colaborativo baseado em afinidades e em confiança, foi sem dúvida um prazer. E também para mim um aprendizado, à medida que abordávamos questões ainda pouco desenvolvidas e conseguíamos equacioná-las no processo de comunicação e de projeto. Ficamos, penso eu, muito distantes daquela arraigada concepção de orientação de tipo "siga o mestre". Acredito que assumir o papel de orientador é colocar-se em uma condição de colaborador que - por já ter triIhado alguns caminhos a mais que seus orientandos - pode ajudá-los a descobrir ou inventar novos caminhos, seus próprios caminhos.

\footnotetext{
2 Trata-se da pesquisa Espaços públicos: relações e articulações entre campos disciplinares - teorias e projeto, com suporte do CNPq (2010 a 2012) e do Fundo Mackenzie de Pesquisa MACKPESQUISA (2009 e 2011).
} 